\title{
ALLELOPATHIC POTENTIAL OF Ipomoea tricolor (CONVOLVULACEAE) IN A GREENHOUSE EXPERIMENT
}

\author{
A.L. ANAYA, ${ }^{1, *}$ D.J. SABOURIN, ${ }^{2}$ B.E. HERNANDEZ-BAUTISTA, ${ }^{1}$ \\ and I. MENDEZ ${ }^{3}$ \\ 'Instituto de Fisiología Celular, UNAM \\ Apdo. Postal 70-243, México 045/O, D.F. \\ ${ }^{2}$ The University of Michigan, Flint \\ 264 MSB Biology Department \\ 303 East Kearsley Street \\ Flint, Michigan 48502-2186 \\ ${ }^{3}$ Instituto de Investigación en Matemáticas Aplicadas y Sistemas, UNAM \\ Ciudad Universitaria \\ México 04510, D.F.
}

\begin{abstract}
The allelopathic potential of Ipomoea tricolor, a plant used in Mexican agriculture to control weeds, and tricolorin $A$, the major phytogrowth inhibitor present in the so-called "resin glycosides" of this plant, have been evaluated by testing leachates of the plant and the compound on the gemination and radicle growth of Amaranthus hypochondriacus, Echinochloa crusgalli, Senna uniflora, $I$. tricolor, and $I$. purpurea. The allelopathic potential of $I$. tricolor was evaluated in a greenhouse experiment with dry 1 . tricolor mixed with sterile and nonsterile soil in pots. A. hypochondriacus was sown in pots containing 1. tricolor, 2-chloro-4-(ethylamino)-6-(isopropylamino)1,3,5 triazine (Gesaprim) or 1-glyphosphate, and the glyphosphate salt of isopropylamine (Faena), two different commercial herbicides used as a comparison to 1 . tricolor. Number and dry weights of different monocotyledonous and dicotyledonous weeds and $A$. hypochondriacus growing in the different treatments were measured. Ipomoea and Faena herbicide had a similar inhibitory effect on monocots.
\end{abstract}

Key Words-Allelopathy, Ipomoea tricolor, Convolvulaceae, tricolorin A. resin glycosides, herbicides.

\section{INTRODUCTION}

The phytotoxic effect of plant residues on the growth of crops and weeds is an aspect that has been extensively studied in allelopathy. Extracts of decomposing

* To whom correspondence should be addressed. 
field residues of barley, rye, broccoli, broadbean, wheat, rice, vetch, and sudangrass, among other crops and weeds, were found to be toxic to the growth of different test species. The challenge is to find plants and residues that are selectively phytotoxic to weeds and with an adequate safety margin on crops (Chou et al., 1977; Altieri and Doll, 1978; Anaya and del Amo, 1978; Ramos et al., 1983; Anaya et al., 1987, 1988; Einhellig and Leather, 1988).

Ipomoea tricolor Cav. (Convolvulaceae) is extensively used in Mexico in folk medicine and agriculture for many purposes. The seeds, with a high content of ergot-type alkaloids, have been used as a hallucinogenic agent in ritual ceremonies by members of the Zapotec and Chatin Indians in Mexico. Other species of the morning glory family are used traditionally all over the world as powerful cathartics. This purgative action is a consequence of the presence of glycosidic resins in foliar tissues, especially in roots and rhizomes of the species belonging to the Convolvulaceae family (Wagner, 1973). In the tropical zones of Mexico, farmers promote the growth of I. tricolor, other species of this genus, and some semidomesticated legumes, e.g., Stizolobium spp., to protect the soil and to control the growth of weeds. In the sugar cane fields of the state of Morelos, México, I. tricolor is grown extensively as a cover crop, especially from August to October. After this time, the whole plant is cut and incorporated into the soil as a green manure. Bioactivity-directed fractionation of organic extracts of the plant led to the isolation of a mixture of resin glycosides with high phytotoxic effects (Anaya et al., 1990). Tricolorin A, the major phytogrowth inhibitor present in the active fraction of the $\mathrm{CHCl}_{3}$ extract (Figure 1) inhibited the radicle growth of Amaranthus hypochondriacus and Echinochloa

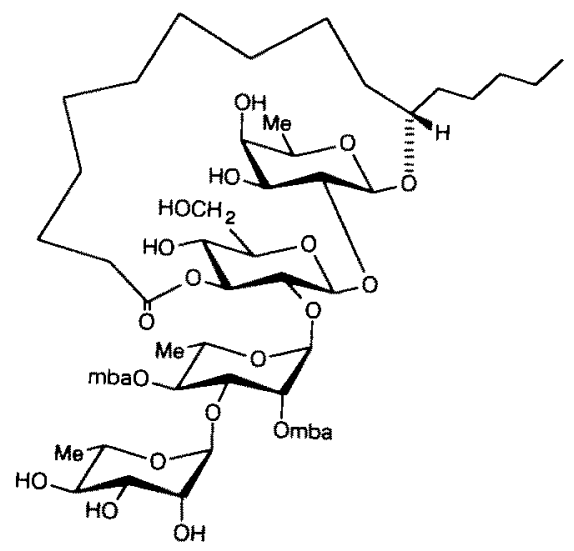

FIG. 1. Structure of tricolorin A (mba, 2-methylbutyroyl). 
crusgalli with $\mathrm{IC}_{50}$ values ranging from 12 to $37 \mu \mathrm{M}$. This bioactive glycolipid displayed a broad range of activities, including antimicrobial and cytotoxic effects and inhibition of protein kinase C activity (Pereda-Miranda et al., 1993).

An objective of the present study was to compare the phytotoxicity of $I$. tricolor leachates and tricolorin $A$ in vitro with that of two commercial herbicides on the germination and growth of $A$. hypochondriacus (Amaranthaceae) and $E$. crusgalli (Poaceae). A second objective was to compare the effect of dry $I$. tricolor incorporated into the soil (sterile and nonsterile) in pots with that of two commercial herbicides on the number and growth of weeds, and the growth of A. hypochondriacus (Amaranthaceae).

\section{METHODS AND MATERIALS}

Whole plants of 1 . tricolor were collected in Cañón de Lobos, Morelos, México, in March 1993. The plant material was air dried and crushed by hand.

Comparative Bioassays for Phytotoxicity. A bioassay was performed to determine the phytogrowth inhibitory effect of the leachate $(2 \%)$ of 1 . tricolor mixed $(50: 50)$ with $1.5 \%$ pure agar. Osmotic pressure was checked to prevent the use of a highly concentrated leachate. Tricolorin A, and two commercial herbicides, 2-chloro-4-(ethylamino)-6-(isopropylamino)-1,3,5 triazine (Gesaprim, Ciba-Geigy), and 1-glyphosate and the glyphosate salt of isopropylamine (Faena, Monsanto) in concentrations of $10,50,100,150$, and $200 \mu \mathrm{g} / \mathrm{ml}$ were tested. Phytogrowth inhibitory activity was determined by seed germination and radicle growth tests on $A$. hypochondriacus, E. crusgalli (Poaceae), Senna uniflora (Fabaceae), I. tricolor, and I. purpurea. Distilled water plus methanol $(9.9: 0.1)$ mixed with $1.5 \%$ agar $(50: 50)$ was used as control.

The bioassay was performed in Petri dishes (10 seeds per dish for $A$. hypochondriacus, E. crusgalli, I. tricolor, and I purpurea, and eight seeds for Senna uniflora) with four repetitions per treatment in a complete block design. Petri dishes were incubated in darkness at $27^{\circ} \mathrm{C}$. Percent germination and radicle growth were obtained after $24 \mathrm{hr}$ for $A$. hypochondriacus and $48 \mathrm{hr}$ for the rest of the test species. Data were analyzed by an ANOVA and Tukey's test.

Greenhouse Experiment. Soil for pots was collected in a crop field recently tilled from a farming community where 1 . tricolor is used as a cover crop for weed control, in the locality of Yautepec, near Cañón Lobos, Morelos, in July 1993. The soil was passed through a $2-\mathrm{mm}$ sieve and divided in two parts. One part was sterilized before the addition of treatments. The experiment was performed in a complete random block design with four blocks. Each block contained 16 representative pots for a total of 64 pots. The pots contained $3 \mathrm{~kg}$ of soil and were rotated every three weeks to ensure uniform sunlight. The following treatments were used. 
Abbreviations Treatments

\begin{tabular}{ll}
\hline IVS & Sterile soil $+2.5 \%$ of vermiculite (control 1) \\
2VS & Sterile soil $+5 \%$ of vermiculite (control 2 ) \\
IVNS & Nonsterile soil $+2.5 \%$ of verniculite (control 3) \\
2VNS & Nonsterile soil $+5 \%$ of vermiculite (control 4 ) \\
IIS & Sterile soil $+2.5 \%$ of $I$ tricolor (dried and milled) \\
2IS & Sterile soil $+5 \%$ of $I$ tricolor (dried and milled) \\
IINS & Nonsterile soil $+2.5 \%$ of $I$. tricolor (dried and milled) \\
2INS & Nonsterile soil $+5 \%$ of $I$ tricolor (dried and milled) \\
IGS & Sterile soil $+2.5 \%$ of vermiculite $+0.4 \%$ of Gesaprim \\
2GS & Sterile soil $+5 \%$ of vermiculite $+0.8 \%$ of Gesaprim \\
IGNS & Nonsterile soil $+2.5 \%$ of vermiculite $+0.4 \%$ of Gesaprim \\
2GNS & Nonsterile soil $+5 \%$ of vermiculite $+0.8 \%$ of Gesaprim \\
IFS & Sterile soil $+2.5 \%$ of vermiculite $+0.4 \%$ of Faena \\
2FS & Sterile soil $+5 \%$ of vermiculite $+0.8 \%$ of Faena \\
IFNS & Nonsterile soil $+2.5 \%$ vermiculite $+0.4 \%$ of Faena \\
2FNS & Nonsterile soil $+5 \%$ of vermiculite $+0.8 \%$ of Faena
\end{tabular}

Gesaprim is a 1,3,5-triazine herbicide with a selective pre- and postemergent action used to control annual weeds. Faena is a phosphonic acid product. a glyphosate that acts as a nonselective, nonresidual postemergent herbicide (Worthing, 1991; Draber and Fujita, 1992). The tested concentrations of herbicides were designed to be similar and higher than the mean content of Tricolorin A in Ipomoea tricolor (Pereda-Miranda et al., 1993).

Five seeds of $A$. hypochondriacus were sown in each pot. After two weeks, pots were thinned to one seedling of $A$. hypochondriacus. Five seeds of $E$. crusgalli and $S$. uniflora were sown in each pot that contained sterile soil. Number of monocotyledonous and dicotyledonous weeds in the nonsterile soil treatments was recorded five times during the experiment. Numbers of $E$. crusgalli and $S$. uniflora were recorded in the sterile soil treatments. The number of 1 . tricolor seedlings in the four treatments that contained this plant incorporated into the soil (sterile and nonsterile) was recorded four times during the experiment. Pots were watered when necessary. Basins were placed underneath each pot in order to collect drainage water, which was refrigerated for further bioassays and chromatographic analysis. After 45 days the experiment was completed. Plants were removed and separated into monocot and dicot weeds and A. hypochondriacus. Plants were dried and weighed. Data were analyzed by an ANOVA, contrasts, and Tukey studentized range tests (Méndez et al., 1992).

Bioassays with Drainage Water from Pots. A bioassay was performed to determine the effects of the drainage water from pots containing each of the treatments in the greenhouse experiment. In this bioassay, the drainage water 
of the pot with the $2.5 \%$ proportion was mixed with that of the pot with $5 \%$ proportion of each treatment to make only eight treatments. These drainage waters were tested on germination and radicle growth of $A$. hypochondriacus and $E$. crusgalli. Bioassay was performed in a complete block design with four repetitions in Petri dishes with Whatman filter paper (No. 42), 10 seeds per treatment. Petri dishes were placed under the same conditions as the comparative phytotoxicity bioassay. Data were analyzed by ANOVA and Tukey's test.

Soil Analysis. Soil samples before and after the greenhouse experiment were analyzed at the Center of Ecology at UNAM in order to measure physical and chemical properties.

\section{RESULTS AND DISCUSSION}

\section{Comparative Bioassays for Phytotoxicity}

Results of the bioassays in Petri dishes testing aqueous leachates of $I$. tricolor, tricolorin A, and the two herbicides, Gesaprim and Faena, on the germination of $A$. hypochondriacus, E. crusgalli, Senna uniflora, Ipomoea tricolor, and I. purpurea are shown in Table 1. Aqueous leachates of the plant significantly inhibited germination of $E$. crusgalli and $I$. tricolor. Tricolorin A was the only treatment that strongly inhibited germination of $A$. hypochondriacus, and to a lesser extent, E. crusgalli. Tricolorin A slightly inhibited I. tricolor and $I$. purpurea germination, as all other treatments had no effect, on $S$. uniflora. a species that coexists with $I$. tricolor in the same habitat. Both herbicides slightly inhibited germination of $A$. hypochondriacus and E. crusgalli. Germination of $I$. tricolor was significantly inhibited by tricolorin A $(100-200 \mu \mathrm{g} / \mathrm{ml})$ and Faena herbicide. Germination of $I$. purpurea was slightly affected by tricolorin $\mathrm{A}$ and Faena.

Results of the bioassays in Petri dishes, which tested the same treatments on the radicle growth of test species, are shown in Table 2. Leachate of $I$. tricolor strongly inhibited the radicle growth of $A$. hypochondriacus and had a slight effect on $E$. crusgalli and $S$. uniflora, but it showed no effect on the radicle growth of the two Ipomoea species tested. Tricolorin A displayed a strong inhibitory effect on radicle growth of $A$. hypochondriacus and $E$. crusgalli. However, this bioactive compound had no effect on $S$. uniflora. Tricolorin A significantly inhibited radicle growth of $I$. tricolor at 150 and $200 \mu \mathrm{g} / \mathrm{ml}$. This inhibitory effect was stronger on $I$. purpurea. The effect of the two herbicides tested in Petri dishes was different to that in the soil. Gesaprim significantly inhibited ( $34 \%$ ) the radicle growth of $A$. hypochondriacus at 150 and 200 $\mu \mathrm{g} / \mathrm{ml}$. It stimulated $A$. hypochondriacus at $10 \mu \mathrm{g} / \mathrm{ml}$, and had no effect on $E$. crusgalli and $S$. uniflora. Gesaprim caused a significant stimulation of radicle 
Table 1. EfFects of Aqueous Leachate and Tricolorin A of Ipomoea tricolor and Gesaprim and Faena Herbicides on Germination of Five Species

\begin{tabular}{|c|c|c|c|c|c|}
\hline \multirow[b]{2}{*}{ Trealments } & \multicolumn{5}{|c|}{ Germination (\%) } \\
\hline & $\begin{array}{c}\text { Amaranthus } \\
\text { hypochondriacus }\end{array}$ & $\begin{array}{l}\text { Echinochloa } \\
\text { crusgalli }\end{array}$ & $\begin{array}{l}\text { Senna } \\
\text { unifora }\end{array}$ & $\begin{array}{l}\text { Ipomoea } \\
\text { tricolor }\end{array}$ & $\begin{array}{l}\text { Ipomoea } \\
\text { purpurea }\end{array}$ \\
\hline Control & 95.0 & 90 & 80 & 65 & 60 \\
\hline Aqueous leachate $(1 \%)$ & 95.0 & $67.5^{t}$ & 100 & $55^{\circ}$ & 60 \\
\hline \multicolumn{6}{|l|}{ Tricolorin A $(\mu \mathrm{g} / \mathrm{ml})$} \\
\hline 10 & $70.0^{a}$ & 92.5 & 80 & 65 & $45^{a z}$ \\
\hline 50 & $57.7^{*}$ & $70^{\circ}$ & 80 & 62.5 & 67.5 \\
\hline 100 & 0 & $35^{a t}$ & 80 & 62.5 & $50^{a t}$ \\
\hline 150 & 0 & $35^{a}$ & 80 & $55^{a}$ & $50^{a}$ \\
\hline 200 & 0 & $27.5^{\prime \prime}$ & 75 & $25^{a}$ & 57.5 \\
\hline \multicolumn{6}{|l|}{ Gesaprim $(\mu \mathrm{g} / \mathrm{m}))$} \\
\hline 10 & 87.5 & 90 & 80 & 90 & $72^{u}$ \\
\hline 50 & 92.5 & 90 & 80 & 70 & 52 \\
\hline 100 & 97.5 & 90 & 72.5 & 76 & 56 \\
\hline 150 & $85^{\prime \prime}$ & 92.5 & 80 & 88 & 52 \\
\hline 200 & $80^{\prime \prime}$ & 82.5 & 80 & 76 & 52 \\
\hline \multicolumn{6}{|l|}{ Faena $(\mu \mathrm{g} / \mathrm{ml})$} \\
\hline 10 & 100 & $77.5^{a}$ & 80 & $47.5^{\prime \prime}$ & 57.5 \\
\hline 50 & 92.5 & $75^{u}$ & 77.5 & $42.5^{i i}$ & 55 \\
\hline 100 & $85^{\prime \prime}$ & 90 & 80 & $55^{i}$ & $50^{a}$ \\
\hline 150 & 87.5 & $75.0^{a}$ & 80 & $42.5^{t i}$ & $47.5^{5}$ \\
\hline 200 & $85^{\prime \prime}$ & $77.5^{a}$ & 80 & $30^{i a}$ & 57.5 \\
\hline
\end{tabular}

${ }^{a}$ Differences statistically significant $(P<0.05$ ) with respect to control using a HSD Tukey's test.

growth of the two Ipomoea species tested. Faena had an inhibitory effect on radicle growth of $E$. crusgalli, $S$. uniflora, I. tricolor, and $I$. purpurea starting at $10-50 \mu \mathrm{g} / \mathrm{ml}$. This herbicide did not affect the growth of $A$. hypochondriacus.

\section{Greenhouse Experiment}

Number of Seedlings of 1 . tricolor in Pots. The dry 1 . tricolor that was mixed with sterile and nonsterile soil (IIS, 2IS, IINS, 2INS), contained some seeds of the species that went unnoticed until they germinated in the pots. The number of seedlings that emerged in these four treatments was recorded four times during the experiment and then was completely eliminated to avoid its competitive effect on the other plants. The split-plot ANOVA made with the logarithms of the number of these seedlings in the four dates recorded showed a significant effect for the interaction date-treatment. 
Table 2. Effects of aqueous leachate and Tricolorin A of Ipomoea tricolor and Gesaprim and Faena Herbicides on Radicle Growth of Five Species

\begin{tabular}{|c|c|c|c|c|c|}
\hline \multirow[b]{2}{*}{ Treatments } & \multicolumn{5}{|c|}{ Radicle growth inhibition (\%) } \\
\hline & $\begin{array}{c}\text { Amaranthus } \\
\text { hypochondriacus }\end{array}$ & $\begin{array}{l}\text { Echinochloa } \\
\text { crusgalli }\end{array}$ & $\begin{array}{c}\text { Senna } \\
\text { uniflora }\end{array}$ & $\begin{array}{l}\text { Ipomoea } \\
\text { tricolor }\end{array}$ & $\begin{array}{l}\text { Ipomoea } \\
\text { purpurea }\end{array}$ \\
\hline Control & 0.0 & 0.0 & 0.0 & 0.0 & 0.0 \\
\hline Aqueous leachate $(1 \%)$ & $60.0^{\circ}$ & $26.4^{\prime \prime}$ & $20.8^{a}$ & 11.6 & 7.0 \\
\hline \multicolumn{6}{|l|}{ Tricolorin A $(\mu \mathrm{g} / \mathrm{ml})$} \\
\hline 10 & $39.7^{i r}$ & $52.2^{i}$ & $(13.1)^{k}$ & (5.4) & 7.2 \\
\hline 50 & $55.0^{a}$ & $72.1^{\prime \prime}$ & 9.3 & 17.3 & $36.7^{\circ}$ \\
\hline 100 & $100^{\prime \prime}$ & 78.2 & 7.7 & 17.1 & $32.6^{a}$ \\
\hline 150 & $100^{4}$ & $78.0^{t t}$ & 8.3 & $32.4^{*}$ & $23.0^{t}$ \\
\hline 200 & $100^{a}$ & $77.5^{a}$ & 4.8 & $40.7^{a}$ & $43.0^{4}$ \\
\hline \multicolumn{6}{|l|}{ Gesaprim $(\mu \mathrm{g} / \mathrm{ml})$} \\
\hline 10 & $(24.0)^{t}$ & $(14.6)$ & (13.1) & $(7.2)$ & $(55.0)^{a t}$ \\
\hline 50 & $(8.0)$ & $(12.8)$ & 5.1 & $(18.4)$ & $(10.0)$ \\
\hline 100 & 19.6 & 3.7 & 10.0 & $(27.0)^{a}$ & $(55.8)^{4}$ \\
\hline 150 & $20.0^{\prime \prime}$ & 11.7 & (6.2) & $(31.0)^{21}$ & $(28.0)^{\prime \prime}$ \\
\hline 200 & $34.4^{t z}$ & $(15.0)$ & 8.2 & $(24.3)^{z}$ & $(70.5)^{a}$ \\
\hline \multicolumn{6}{|l|}{ Faena $(\mu \mathrm{g} / \mathrm{ml})$} \\
\hline 10 & $(1.8)$ & $25.0^{\prime \prime}$ & $(15.9)$ & $41.8^{\prime \prime}$ & $46.0^{\prime \prime}$ \\
\hline 50 & $(6.0)$ & $41.2^{4}$ & $40.9^{a}$ & $46.4^{4}$ & 55.4 \\
\hline 100 & $(7.5)$ & $55.5^{\prime \prime}$ & $42.9^{a}$ & 53.4 & $59.7^{x}$ \\
\hline 150 & $(1.8)$ & $69.1^{\prime \prime}$ & $52.3^{\prime \prime}$ & $66.5^{a}$ & $58.5^{\alpha}$ \\
\hline 200 & 18.6 & $75.0^{*}$ & $52.3^{a}$ & $61.4^{4}$ & $66.0^{4}$ \\
\hline
\end{tabular}

"Differences statistically significant $(P<0.05)$ with respect to control using a HSD Tukey's test.

"Number in parentheses indicates stimulation.

The analysis of interaction of treatments by dates on number of seedlings of Ipomoea is shown in Figure 2. There was a significant difference in the number of seedlings of $I$. tricolor in sterile (1IS and 2IS) and nonsterile (1INS and 2INS) treatments, particularly in the first date. There was a significant difference between IINS treatment (prepared with the low proportion of $I$. tricolor added to soil) and the other three treatments in the second, third, and fourth measurements. Probably, in nonsterile soil, microorganisms quickly attack the seed population of $I$. tricolor, diminishing the possibility of germination and survival. Absence of microorganisms in sterile soil may have favored the integrity of Ipomoea seeds and their probability of survival and germination. With time, conditions of soil sterility were lost, and the number of germinated seeds came to be similar in all treatments, except in the IINS. It is possible that in natural conditions, $I$. tricolor inhibits germination and growth of its own seeds. 


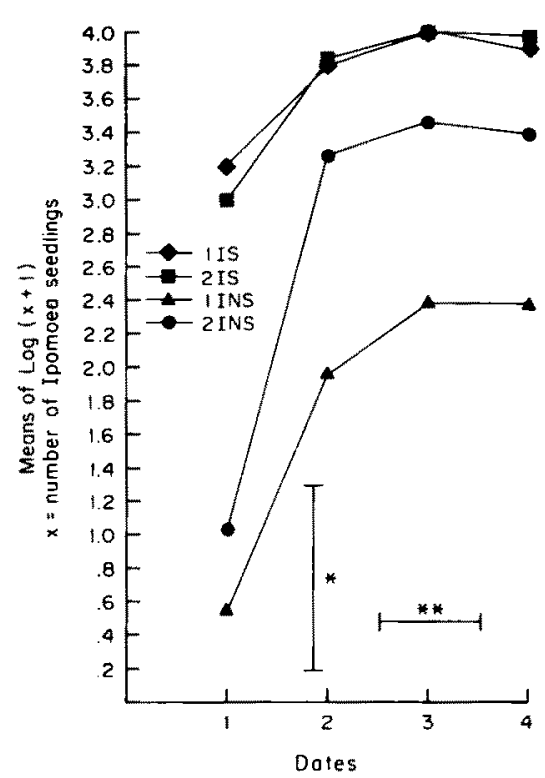

Fic. 2 Study of the interaction treatments by dates on number of seedlings of Ipomoea (all experimental data). ${ }^{*}$ HSD for comparing treatments; ${ }^{*}$ HSD for comparing dates.

The phytotoxic activity of the leachates and/or residues could be an autocontrol mechanism of the population. These seeds are rich in alkaloids and other important secondary metabolites, including resin glycosides, so it is also important to explore the ecological role that these compounds play in the establishment of biotic interactions, especially with predators and microorganisms.

Effects of Treatments on Number of Echinochloa (Monocot) and Senna (Dicot) Plants in Sterile Soil. The number of plants for each pot was recorded five times during the experiment. ANOVA showed that there was a significant difference among treatments. For both plant types, it is also possible to observe a significant effect for the interaction treatments-dates.

Tukey's studentized range test for the means of the logarithm of number of Echinochloa (monocot) plants in sterile soil (Table 3) shows that the number of plants is higher in control 2VS compared with the other treatments. There was no difference among IVS, IIS, 2IS, and 2FS. These four treatments were different from 1FS, 1GS, and 2GS. These last two treatments were statistically different from each other and from 1IFS. The number of Echinochloa was significantly diminished by both Gesaprim treatments and treatment with Faena in low concentration (1FS). 
Table 3. Tukey's Studentized Range Test for Logarithm of Number of Echinochloa (Monocot) and Senna (Dicot) Plants in Sterule Soll ${ }^{a}$

\begin{tabular}{|c|c|c|c|}
\hline \multicolumn{2}{|c|}{ Echinochloa (monocot) } & \multicolumn{2}{|c|}{ Senna (dicot) } \\
\hline Treatment & Mean & Treatment & Mean \\
\hline $2 \mathrm{VS}$ & $1.40 \pm 0.61 \mathrm{a}$ & 2VS & $1.56 \pm 0.38 \mathrm{~A}$ \\
\hline $2 \mathrm{FS}$ & $1.30 \pm 0.75 \mathrm{ab}$ & $2 \mathrm{FS}$ & $1.40 \pm 0.34 \mathrm{~A}$ \\
\hline IVS & $1.28 \pm 0.73 \mathrm{ab}$ & 2IS & $1.35 \pm 0.48 \mathrm{AB}$ \\
\hline 2IS & $1.25 \pm 0.72 \mathrm{ab}$ & IVS & $1.33 \pm 0.75 \mathrm{AB}$ \\
\hline IIS & $1.21 \pm 0.71 \mathrm{ab}$ & IIS & $1.31 \pm 0.19 \mathrm{AB}$ \\
\hline IFS & $1.08 \pm 0.73 \mathrm{bc}$ & IFS & $1.02 \pm 0.32 \mathrm{BC}$ \\
\hline $2 G S$ & $0.87 \pm 0.74 \mathrm{~cd}$ & $2 \mathrm{GS}$ & $0.70 \pm 0.78 \mathrm{DC}$ \\
\hline IGS & $0.66 \pm 0.64 d$ & IGS & $0.35 \pm 0.40 \mathrm{D}$ \\
\hline
\end{tabular}

${ }^{a}$ Numbers with different letters are significantly different $(\rho<0.05)$.

The number of Senna (dicot) (Table 3) was the same in the control 2VS and Faena in high concentration (2FS). The control IVS and the treatments IIS and 2IS are not different from each other. The other treatments (IFS, 2GS, and 1GS) were significantly different. In fact, the number of Senna plants was significantly diminished by the two treatments with Gesaprim and Faena in low concentration. Ipomoea treatments affected the number of Senna only when compared with $2 \mathrm{VS}$ control and Faena in high concentration. The effect of Faena was unexpected when the results of the low and high concentrations were compared. The number of Senna and Echinochloa seedlings was affected only by the low concentration of Faena.

The analysis of interaction of treatments by dates on number of Echinochloa (monocot) plants in sterile soil is shown in Figure 3. Faena at low concentration (1FS) had the lowest number of seedlings at the second and third dates. There was a significant difference between both Gesaprim treatments and the other treatments at the fourth and fifth dates.

The analysis of interaction of treatments by dates on number of Senna (dicot) plants in sterile soil is shown in Figure 4. Regarding differences among treatments, Gesaprim and Faena at low concentration had low numbers of Senna plants at the third and fourth dates. At these same dates, control 2VS had the higher number of plants. Both concentrations of Gesaprim (1GS and 2GS) were significantly different from the other treatments in the fourth and fifth dates. Gesaprim and Faena at low concentration (1GS and 1FS) had a stronger effect on the number of Echinochloa and Senna plants compared with the high concentration (2GS and 2FS). 


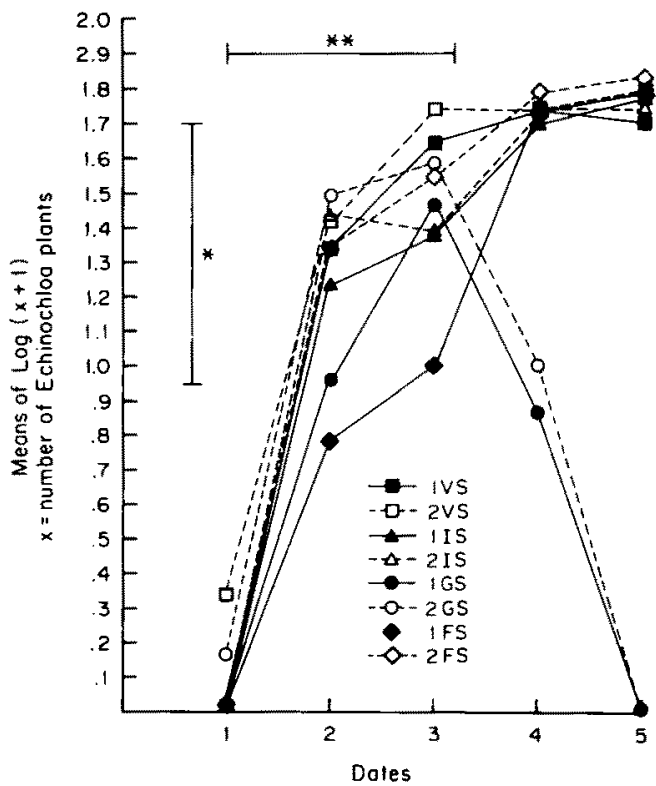

Fig. 3 Study of the interaction treatments by dates on number of Echnochloa plants (only data for sterile soil). ${ }^{*} \mathrm{HSD}$ for comparing treatments; ${ }^{* *} \mathrm{HSD}$ for comparing dates.

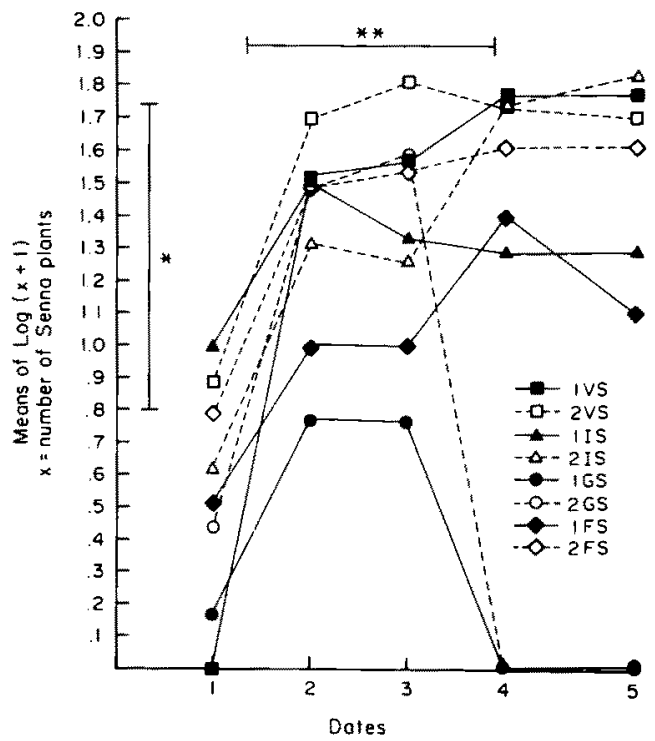

FIG. 4 Study of the interaction treatments by dates on number of Senna plants (only data for sterile soil). *HSD for comparing treatments; ${ }^{* *}$ HSD for comparing dates. 
Table 4. Tukey's Studentized Range Test for Logarithm of Number of Monocotrledonous and Dicotyledonous Plants in Nonsterile Soll ${ }^{\circ}$

Monocotyledonous plants

\begin{tabular}{llll}
\hline Treatment & \multicolumn{1}{c}{ Mean } & Treatment & \multicolumn{1}{c}{ Mean } \\
\hline 2VNS & $1.09 \pm 0.42 \mathrm{a}$ & IVNS & $2.26 \pm 0.23 \mathrm{~A}$ \\
IVNS & $1.09 \pm 0.40 \mathrm{a}$ & $2 \mathrm{VNS}$ & $2.24 \pm 0.12 \mathrm{~A}$ \\
lFNS & $0.97 \pm 0.64 \mathrm{a}$ & $1 \mathrm{FNS}$ & $1.53 \pm 0.33 \mathrm{~B}$ \\
IINS & $0.73 \pm 0.49 \mathrm{ab}$ & IINS & $1.41 \pm 0.27 \mathrm{~B}$ \\
2INS & $0.52 \pm 0.41 \mathrm{bc}$ & 2 INS & $1.24 \pm 0.34 \mathrm{~B}$ \\
2FNS & $0.37 \pm 0.23 \mathrm{bcd}$ & 2FNS & $0.81 \pm 0.26 \mathrm{C}$ \\
2GNS & $0.10 \pm 0.23 \mathrm{~cd}$ & IGNS & $0.55 \pm 0.69 \mathrm{C}$ \\
IGNS & $0.07 \pm 0.15 \mathrm{~d}$ & $2 \mathrm{GNS}$ & $0.54 \pm 0.68 \mathrm{C}$
\end{tabular}

"Numbers with different letters are significantly different $(\rho<0.05)$.

Effects of Treatments on Number of Monocoryledonous and Dicoryledonous Plants in Nonsterile Soils. The split-plot ANOVA with the logarithms of the number of monocotyledonous and dicotyledonous plants in nonsterile soils showed that there was a significant difference between treatments. In the case of the number of dicotyledonous plants, there was a significant effect for the interaction treatments-dates. Tukey's studentized range test for the logarithm of the number of monocots in nonsterile soil (Table 4) showed that the two controls (IVNS, 2VNS) and IFNS are not different. The rest of the treatments were different from each other. The number of monocots was significantly diminished by lpomoea and Faena in high concentration; this effect was stronger with Gesaprim in both concentrations. In relation to the number of dicots, it was observed that treatments IFNS, IINS, and 2INS were significantly different from the controls. Treatments 2 FNS, 1GNS, and 2 GNS had a strong phytotoxicity on the number of dicots.

The analysis of interaction of treatments by dates on the number of monocotyledonous plants in nonsterile soil is shown in Figure 5. The two controls maintained the higher number of monocots from the beginning of the experiment. At the fourth and fifth dates, this is true also for Faena at low concentration. The two treatments with Ipomoea had a low number of monocots from the first to the fourth dates. Both treatments with Gesaprim differed from the other treatments from the third date to the final date. Faena at high concentration was significantly different from Faena at low concentration. It is possible to see that the effect of Ipomoea treatments is stronger compared with Faena at low concentration.

The analysis of interaction of treatments by dates on the number of dico- 


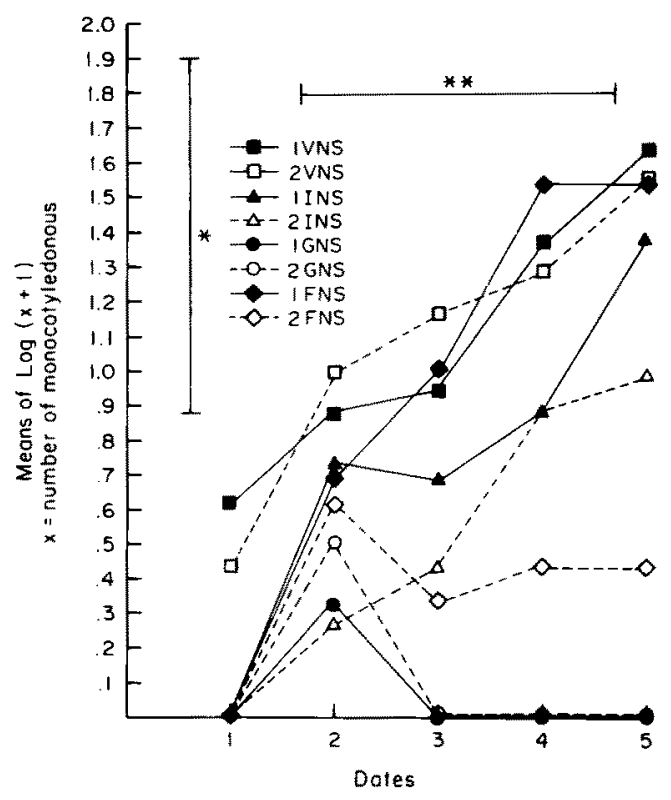

FIG. 5 Study of the interaction treatments by dates on number of monocotyledonous (only data for non-sterile soil). *HSD for comparing treatments: **HSD for comparing dates.

tyledonous plants in nonsterile soil is shown in Figure 6. Both controls had the higher number of dicots at the five dates recorded. At the first date both Ipomoea treatments and Gesaprim at the low concentration had the lower numbers of dicots. Ipomoea treatments and Faena at low concentration showed a similar effect on the number of dicots from the second date to the fifth date. From the third date to the end of the experiment, 2FNS and both Gesaprim concentrations had a strong phytotoxic effect on dicots.

Gesaprim herbicide eliminated all plants in the pots at the two concentrations used at the end of the experiment. The effect of Gesaprim on growth of plants in sterile and nonsterile soil was opposite to its effect in Petri dishes. In general, Gesaprim did not affect germination and growth of the test species in Petri dishes bioassays. Undoubtedly, the mediator role of the soil is a fundamental factor for the phytotoxic expression of this herbicide. On the other hand, Faena did not affect germination and growth of Amaranthus in vitro, nor the germination of Senna, but it inhibited significantly the radicle growth of Echinochloa, Senna, Ipomoea tricolor, and I. purpurea seedlings in these Petri dish bioassays. 


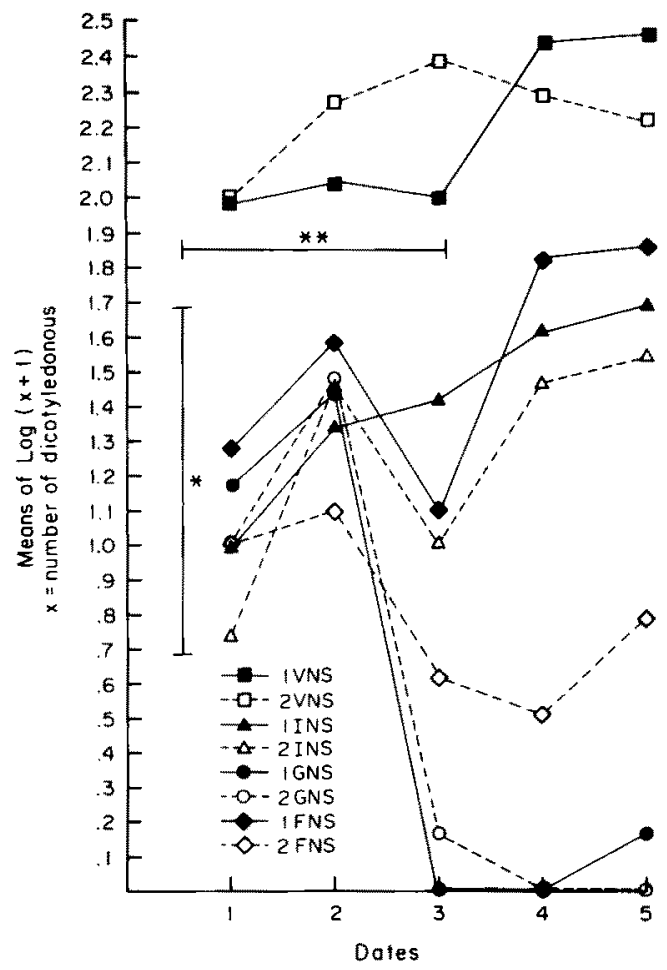

FIG. 6 Study of the interaction treatments by dates on number of dicotyledonous (only data for non-sterile soil). *HSD for comparing treatments: **HSD for comparing dates.

Effects on Echinochloa and Senna Biomass in Sterile Soils and Monocot and Dicot in Nonsterile Soils. Biomass, expressed as dry weight, was evaluated at the end of the experiment. Mean weights of Echinochloa (monocot) and Senna (dicot) in sterile soil, and monocots and dicots in nonsterile soil are shown in Table 5. Gesaprim eliminated all the plants at the two concentrations tested in sterile and nonsterile soils. In relation with sterile soil, the significant difference between treatments is focused on the effect of Ipomoea mixed in the soil and on biomass of Echinochloa. In relation with nonsterile soils, there was no significant difference in the biomass of monocots and dicots in the control, Ipomoea, and Faena treatments. On the other hand, there were no significant differences in the biomass of Aviaranthus hypochondriacus among all the treatments (data not shown). 
Table 5. Effects of Eight Treatments on Biomass of Echinochloa and Senna Plants in Sterile Solls and Biomass of Monocots and Dicots in Nonsterile SolLs

\begin{tabular}{|c|c|c|c|}
\hline \multirow[b]{2}{*}{ Treatment } & \multicolumn{2}{|c|}{ Mean weight ( $\mathrm{g}$ ) } & \multirow[b]{2}{*}{ Total } \\
\hline & Echinochloa & Senna & \\
\hline \multicolumn{4}{|l|}{ Sterile soil } \\
\hline IVS & 2.2 & 0.15 & 2.35 \\
\hline 2VS & 2.78 & 0.15 & 2.93 \\
\hline IIS & $1.6^{n}$ & 0.12 & 1.72 \\
\hline 2IS & $1.25^{\mathrm{z}}$ & 0.11 & 1.36 \\
\hline lGS & 0 & 0 & 0 \\
\hline $2 \mathrm{GS}$ & 0 & 0 & 0 \\
\hline $1 \mathrm{FS}$ & 2.02 & 0.11 & 2.13 \\
\hline 2FS & 2.12 & 0.10 & 2.22 \\
\hline \multirow[t]{2}{*}{ Total } & 11.97 & 0.74 & 12.71 \\
\hline & $\begin{array}{l}\text { Mean weight } \\
\text { (g) of } \\
\text { monocot }\end{array}$ & $\begin{array}{c}\text { Mean weight }(\mathrm{g}) \\
\text { of dicot }\end{array}$ & \\
\hline \multicolumn{4}{|c|}{ Nonsterile soil } \\
\hline IVNS & 0.03 & 0.08 & 0.11 \\
\hline 2VNS & 0.007 & 0.09 & 0.097 \\
\hline IINS & 0.09 & 0.16 & 0.25 \\
\hline 2INS & 0.013 & 0.13 & 0.143 \\
\hline IGNS & 0 & 0 & 0 \\
\hline $2 \mathrm{GNS}$ & 0 & 0 & 0 \\
\hline IFNS & 0.003 & 0.04 & 0.043 \\
\hline 2FNS & 0.005 & 0.0017 & 0.0067 \\
\hline Total & 0.148 & 0.50 & 0.6497 \\
\hline
\end{tabular}

"Differences statistically significant $(\rho<0.01)$ with respect to control using a HSD Tukey's test.

\section{Results of Bioassay with Drainage Water from Pots}

The results from this bioassay are shown in Table 6 . Effects of the drainage water from sterile and nonsterile soil treatments on radicle growth of $A$. hypochondriacus and $E$. crusgalli were different. It is possible to see that there was a specific response of each species to the treatments. ANOVA and Tukey's test showed that significant effects, particularly stimulations, were produced only by drainage water from nonsterile soils. The water from pots with 1 . tricolor produced a significant stimulation of radicle growth of $A$. hypochondriacus. Drainage water from Faena treatments significantly inhibited the growth of this species. 
Table 6. Effects of the Leachates from the Pots on the Radicle Growth of Amaranthus hypochondriacus AND Echinochloa crusgalli.

\begin{tabular}{ccc}
\hline & \multicolumn{2}{c}{ Inhibition (\%) } \\
\cline { 2 - 3 } Treatment & $\begin{array}{c}\text { Amaranthus } \\
\text { hypochondriacus }\end{array}$ & $\begin{array}{c}\text { Echinochloa } \\
\text { crusgalli }\end{array}$ \\
\hline Sterile soil & 0 & \\
VS & $(8)^{t}$ & 0 \\
IS & 1 & $(2)$ \\
GS & 3 & $(3)$ \\
FS & 0 & $(4)$ \\
Nonsterile soil & $(24)^{a}$ & 0 \\
VNS & 9 & $(54)^{a}$ \\
INS & $44^{a}$ & $(47)^{a}$ \\
GNS & & $(36)$ \\
FNS & & \\
\hline
\end{tabular}

${ }^{a}$ Differences statistically significant $(P<0.05)$ with respect to control using a HSD Tukey's test. Numbers in parentheses are stimulations.

On the other hand, E. crusgalli was significantly stimulated by water from pots with I. tricolor, Gesaprim, and Faena. Neither of the phytotoxic agents from the different treatments, except that from Faena, was leached out by the drainage waters. If we compare the results of the bioassays in Petri dishes (Table 2) with these of the drainage waters bioassays (Table 6), we can observe the essential effect of the soil on the expression of phytotoxicity and allelopathy. In relation to this, the effectiveness of a soil-applied herbicide depends on its adsorption in the soil. Organic matter is the predominant adsorbing component in it, so the amount of organic matter in the soil is a determining factor (Johnston, 1986; Rowell, 1994). The selectivity of triazines, for instance, results from their low solubility in water and their high colloidal absorption grade in the soil, so they have relatively long-term activity in the soil. This could explain the strong phytotoxicity of Gesaprim in the soil of the experiment that was rich in organic matter (Gerber et al., 1970; Addiscot and Wagenet, 1985).

Table 7 shows some physical and chemical properties of soil before and after the experiment. In general, conditions of the soil before and after the experiment change slightly. Before the experiment, sterilization of the soil increased total nitrogen and total phosphorus. After the experiment, the $\mathrm{pH}$ tended to be neutral. The soil was not saline, but Ipomoea and Gesaprim caused a small increase in the electrical conductivity of it. Organic matter is higher in sterile and nonsterile soil with Ipomoea and in soil of the nonsterile control and 


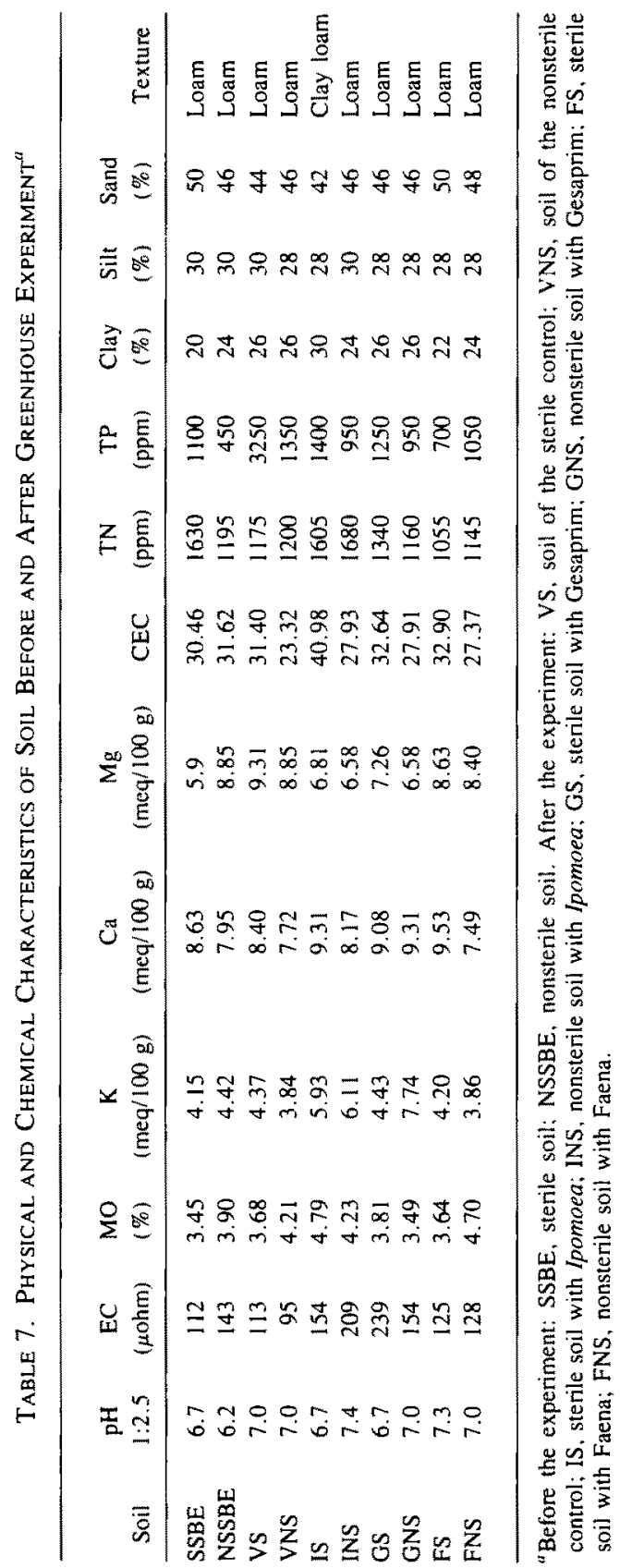


nonsterile soil with Faena. Potassium was increased in Ipomoea treatments and in nonsterile soil with Gesaprim. Nitrogen was increased in sterile soil before the experiment and in both treatments with Ipomoea. Phosphorus is higher in almost all the sterile soils compared with the nonsterile ones.

In the greenhouse experiment, the biomass of Echinochloa crusgalli (sterile soil) was significantly diminished by the incorporation of $l$. tricolor into the soil, and also, the number of monocots and dicots in nonsterile soil. In fact, the number of monocots and dicots tended to diminish starting from the third date recorded in the greenhouse experiment in both Ipomoea treatments. It is possible to see that this tendency is stronger comparing these two treatments with Faena at low concentration. In the field, it is possible that the weed control effect of Ipomoea tricolor takes place in two stages, first, by the combination of the allelopathic potential of the living plant expressed through rain leachate and competition (interference); and second, when the plant is cut and incorporated into the soil. Decomposition of its residues acts as the second weed control factor before the sowing of sugar cane, corn, or other crops.

Acknowledgments-This work was partially sponsored by projects 1179-N9202 (CONACYT), D-III-90355I (CONACyT), and IN-203394 (DGAPA-UNAM). We thank Dr. Rogelio PeredaMiranda for his valuable help and comments, and Ms. Andrea Torres Barragán and Maria del Carmen Flores Carmona for their skillful assistance.

\section{REFERENCES}

ADDiscor, T.M., and WAGENET, R.J. 1985. Concepts of solute leaching in soils: A review of modelling approaches. J. Soil Sci. 36:411-424.

ALTIERI, M.A., and DOL.. J.D. 1978. The potential of allelopathy as a tool for weed management in crops. PANS 24:495-502.

ANAYA, A.L., and DEL AMO, S. 1978. Allelopathic potential of Ambrosia cumanensis H.B.K. (Compositae) in a tropical zone of México. J. Chem. Ecol. 4:289-304.

anaya, A.L., Ramos, L., Cruz, R., Hernandez, J., and Nava, V. 1987. Perspectives on Allelopathy in Mexican Traditional Agroecosystems: A case study of Tlaxcala. J. Chem. Ecol. 13:2083-2101.

Anaya, A.L., Gliessman, R.S. Cruz, O.R., Rosado-May, F., and Nava, R.V. 1988. Comparative effects of allelopathic weeds used as cover crop on the foristic potential of soils, pp. 607-613, in P. Allen and D. Van Dusen (eds.). Global Perspectives on Agroecology and Sustainable Agriculture: Proceedings of the Sixth International Scientific Conference of the International Federation of Organic Movements (IFOAM). University of Califomia.

Anaya, A.L. Calera, M.R., Mata, R., and Pereda Miranda, R. 1990. Allelopathic potential of compounds isolated from Ipomoea tricolor Cav. (Convolvulaceae). J. Chem. Ecol. 16:21452152.

Draber, W., and FustTa, T. 1992. Rational Approaches to Structure, Activity, and Ecotoxicology of Agrochemicals. CRC Press, Boca Raton, Florida.

Chou, C.H., LIN, T.J., and KAO, C.I. 1977. Phytotoxins produced during decomposition of rice stubbles in paddy soil and their effect on leachable nitrogen. Bot. Bull. Acad. Sin. 18:45-60. 
EinHELLIG, F.A., and LEATHER. G.R. 1988. Potentials for exploiting allelopathy to enhance crop production. J. Chem. Ecol. 14:18-29.

Geraer, H.R., Ziegler. P., and Dubach, P. 1970. Leaching as a toll in the evaluation of herbicides. Proceedings of the 10th British Weed Conference 1:188-225.

Johnston, A.E. 1986. Soil organic matter, effects on soils and crops. Soil Use Manage. 2:97-104.

MAXWELL, S.E., and DELANEY, H.D. 1990. Designing experiments and analysing data. A model comparison perspective. Wadsworth Publishing Co.

Méndez, 1., Posadas, A., Mundo, E., and Marin. S., 1992. Análisis de experimentos con observaciones repetidas. Un ejemplo farmacológico. VII Foro Nacional de Estadística. Puebla, México.

Pereda-Miranda, R., Mata, R., Anaya, A.L., Pezzuto, J.M. Wickramaratne, D.B.M., and KINGHORN, A.D. 1993. Structure and biological activities of tricolorin A, major phytogrowthinhibitor from Ipomoea tricolor. J. Nat. Prod. 56:571-582.

Ramos, L., Anaya, A.L., and Nieto de Pascual, J. 1983. Evaluation of the allelopathic potential of the dominant herbaceous species in a coffee plantation. J. Chem. Ecol. 9(8): 1079-1097.

RowelL, D.L. 1994. Soil Science. Methods and Applications. Longman Scientific \& Technical. Essex, England.

WAGNER. H. 1973. The chemistry of resin glycosides of the Convolvulaceae family, pp. 235-240, in G. Bendz and J. Santesson (eds.). Medicine and Natural Sciences. Chemistry in Botanical Classification. Academic Press, New York.

Worthing, C.R. (ed.). 1991. The Pesticide Manual. British Crop Protection Council. 